MANTHAN: Journal of Commerce and Management Volume 4, Issue 2, July-December 2017, pp. 113-136 doi: 10.17492/manthan.v4i02.11458

\title{
Employee Perception of Human Resource Management Policies: A Study of Insurance Sector in Rajasthan
}

\author{
Mayank Agarwal*
}

\begin{abstract}
Modern age is of significant cut-throat competition where companies in almost every sphere especially service sector are attempting hard to gain the confidence of customers by rendering them value added service and quality path-breaking products. The intent of this paper is to examine the impact of human resource management (HRM) practices on employees as well as the organisation, particularly in the insurance sector in two major cities of Rajasthan state. Three categories of human resources in the insurance sector were selected for the study sample. Further, due consideration was also given to the nature and status of employees to make the sample representative and to elicit most representative views on various aspects and practices of HRM in multiple proportions. Demographic profile and every important element of HRM that plays a significant role in improving and maintaining viable relations between the employee and employer have been discussed. Their role in improving the financial health and credit worthiness of the organisation is also discussed. The findings of this study also indicate that better HRM practices have immense positive impact on employees in the form of higher degree of satisfaction, dedication and higher retention which ultimately results in eventful success of the organisation.
\end{abstract}

Keywords: HRM practices; Organisation; Employees; Recruitment; Training.

\subsection{Introduction}

Insurance sector in India is observing one of the highest turnover rates in human resources. As human resources are one of the most important resources for insurance sector, the rising rate of turnover is the greatest challenge. Employees, particularly in middle and junior levels of the sales office, tend to move amongst insurance companies.

*Assistant Professor, Department of Commerce, Dr H. S. Gour (Central) University, Sagar. Madhya Pradesh, India.(Email id: mayank_agin@yahoo.co.in) 
Employee turnover has long term negative impact on an organisation in terms of its goodwill, competency, profit and level of performance. Quality work force and its retention is one of the crucial determining factors in the company's success. Hence private insurance service providers require implementing efficacious employee retention strategies which can successfully retain the employees for longer duration. This study investigates the human resource management (HRM) practices and their effects on employees' functioning in addition to their impact on organisational well-being. It is a well-known fact that HRM practices have been researched widely in various manufacturing enterprises and some of the service sectors. It is to be examined how far is the HRM atmosphere a more significant determinant of productivity in the insurance sector in comparison to other sectors.

By now, it has been established that employees do exist as vital basis of immense benefit for any organisation. Consequently, it follows that the organisation needs to embrace some of the HRM practices that make the optimum use of its employees. This tendency has been attributed to increased awareness about the impact of HRM on organisation functioning and diverse actions of organisation presentation. The impact of HRM practices on organisation functioning has become the overriding research topic in the personnel management. Several studies have divulged that impact of human resource management practices do bring noticeable change on the employee' contentment, their dedication to the organisation concerned, besides their retention and existence amid people and management leave aside their participation, faith and commitment. Nevertheless certain studies have brought out that these thoughts coupled with well-designed HRM practices may also result in augmentation of organisations' revenue, its profits, market capitalisation, share value, improved quality, client satisfaction and scope for further inflow of investments. Hence, the impact of human resource management on workforce and functioning of organisation is an imperative subject in the area of management and industrial relations. Quality of good HRM system is judged from the sound set of practices that boost employees' skill and capabilities, empowerment and active participation in firm's decision making. As a corollary, in the absence of suitable and properly designed tailor made human resource management, the organisation will be unable to attain reputable positions; therefore, managing efficient management of human resources is the answer to success of any organisation.

These practices include policies concerning employee's recruitment and selection procedure, training, physical and mental well-being, rewards and participation in the decision-making procedure. Well-designed HRM practices do improve organisation efficacy and performance by pulling, naming, and holding employees with know-how, skills, ability and training them to perform in a style that will sustain the duty 
and targets of the group. Hence, the usefulness of HRM practices hinges on how it develops the required attitude and manners in employees, apart from its accomplishment. No doubt, such course of action need sizeable investments in training, synchronization of initiatives, and time for input. For the reason of sizeable investment in human capital, it becomes obvious that the value of these practices is offset by improvement in efficiency and efficacy. Figure 1 depicts (i) the link between HRM and performance (ii) HRM activities, outcomes and performance.

\section{Figure 1: Model of the Link between HRM and Performance}

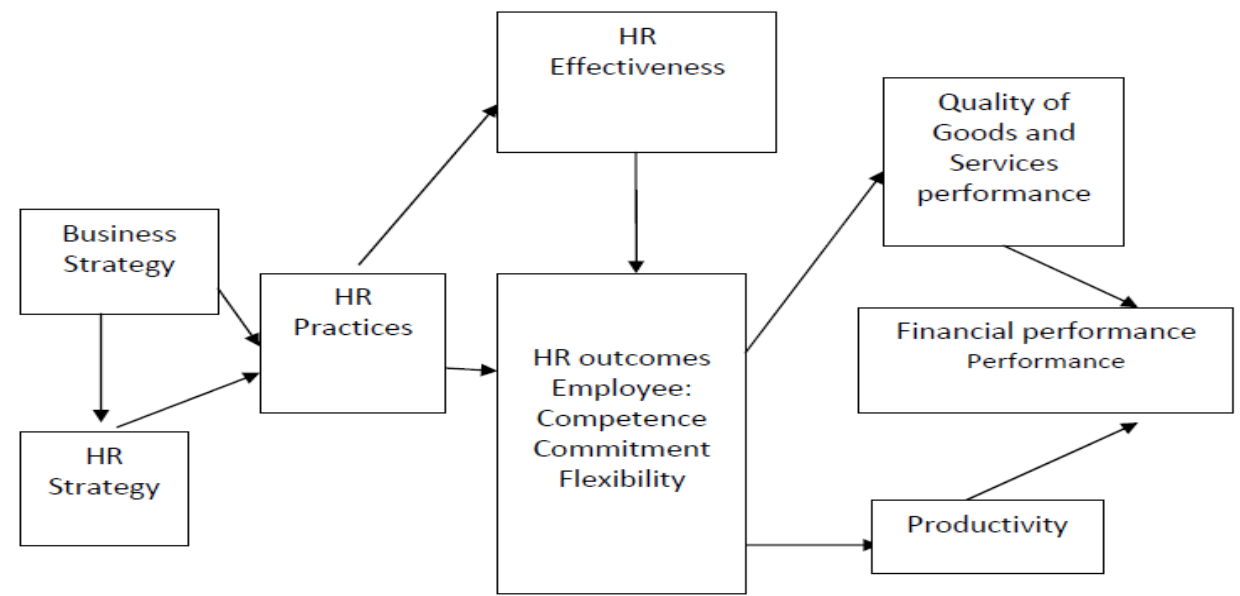

Source: Armstrong (2006)

\subsection{Review of Literature}

While acknowledging that HRM serves as a value-creating function, there are some issues unresolved and some questions open. These issues can be summarised under the umbrella of the plea of Guest (1997) that there is a need for theory on HRM, theory on performance and theory on how the two are linked. It is generally accepted that "people are the key assets in the new world market and that all other assets are nothing more than commodities that can be purchased at market prices, because only the human asset has potential to learn, grow, and contribute" (Fitz-enz, 1995). Becker (1996) questions as to "how do human resource decisions influence organizational performance?" Due to fact that "there is a little understanding of the mechanisms through which HRM practices influence effectiveness", one of the main challenges for 
researchers is to explicate and to assess the precise pathway through which HRM practices influence organizational performance. (Delery, 1998)

Venkatraman and Ramanujam (1986) indicate that a narrow definition of performance focus on the use of simple outcome-based financial indicators that are assumed to reflect the fulfilment of the economic goals of the firm. Becker and Huselid (1997) provided one of the more detailed models of the relationship between HR practices and firm performance offered to date. In essence, this model suggests that business strategies drive the design of the HR system. The HR system directly impacts employee skills and motivation and the structure and design of work. These factors influence employee behaviour, which translates into improved operating performance. This drives profits and growth, which result in market value. Financial performance measures do not represent the operational performance of the company and are more subject to the process of value appropriation on the part of actors involved (Crook et al., 2011). HR practices can be evaluated by their impact on employees' skills, their motivation and effort, and the opportunities they have to contribute (Jiang et al., 2012).

\subsection{Critical Discussion on HRM Practices: What Employees and Employers think about them?}

This analysis was based on secondary as well as primary data on the subject. The primary data was collected and analysed on the basis of well thought-out questionnaire. The basic aim of the questionnaire was to reach and ascertain the perceptions of the employees better known as senior officers, managers and agents. The questionnaire was distributed among randomly selected employees representing these categories with the intention of ascertaining their views on different facets of human resource management realities in the sector.

\subsection{Sample design and profile of respondents}

The analysis is limited to insurance sector of the state of Rajasthan. Only limited studies are well known in so far as the insurance industry in private sector is concerned, and they have been either restricted to a single unit or a specific district. In contrast, this study has been structured so as to broaden the scope to the extent of private insurance sector located in Jaipur and Ajmer districts of the state of Rajasthan. For this study, sample of 150 employees of insurance units located in Jaipur and Ajmer Districts of Rajasthan was chosen on a random sample basis. 
For the study, three sample categories of human resource in the insurance sector were selected, i.e. senior officers, managers and agents. While doing so, due consideration was also given to include permanent employees as well as temporary employees to make the sample representative, and to elicit representative views on various aspects and practices of Human Resources Management in multiple proportions. Table 1 provides the demographic profile of the respondents.

Table 1: Demographic Profile of Respondents

\begin{tabular}{|c|c|c|c|}
\hline \multicolumn{2}{|c|}{ Demographic Variables } & No. of Respondents & Percentage \\
\hline \multirow{6}{*}{ Age (in years) } & Under 21 & 9 & 6.0 \\
\hline & $21-30$ & 51 & 34.0 \\
\hline & $31-40$ & 64 & 42.7 \\
\hline & $41-50$ & 16 & 10.7 \\
\hline & 51 or Older & 10 & 6.7 \\
\hline & Total & 150 & 100.0 \\
\hline \multirow{4}{*}{$\begin{array}{l}\text { Employee' } \\
\text { category }\end{array}$} & Senior Officer & 6 & 4.0 \\
\hline & Manager & 53 & 35.3 \\
\hline & Agents & 91 & 60.7 \\
\hline & Total & 150 & 100.0 \\
\hline \multirow{3}{*}{ Gender } & Male & 127 & 84.7 \\
\hline & Female & 23 & 15.3 \\
\hline & Total & 150 & 100.0 \\
\hline \multirow{4}{*}{$\begin{array}{l}\text { Income level per } \\
\text { annum }\end{array}$} & Less than $3,00,000$ & 48 & 32.0 \\
\hline & $3,00,000-6,00,000$ & 67 & 44.7 \\
\hline & More than $6,00,000$ & 35 & 23.3 \\
\hline & Total & 150 & 100.0 \\
\hline \multirow{4}{*}{ Educational Level } & Graduate and less & 73 & 48.7 \\
\hline & Post Graduate & 66 & 44.0 \\
\hline & Professional degree & 11 & 7.3 \\
\hline & Total & 150 & 100.0 \\
\hline \multirow{5}{*}{$\begin{array}{l}\text { Tenure of working } \\
\text { in the Company }\end{array}$} & 3-5 years & 23 & 15.3 \\
\hline & 5-10 years & 54 & 36.0 \\
\hline & 10-20 years & 59 & 39.3 \\
\hline & More than 20 years & 14 & 9.3 \\
\hline & Total & 150 & 100.0 \\
\hline
\end{tabular}

Source: Author's own 
It can be observed from Table 1 that from amongst 150 representative sample respondents, in the matter of age, a greater part, that is $64(42.7 \%)$ respondents, belong to the age group of $31-40$, followed by $34 \%$ in $21-30$ age group, $10.7 \%$ in the $41-50$ years of age group, $6.7 \%$ in the age group of more than 51 and rest of the respondents $(6 \%)$ in age group of less than 21 years. In terms of gender, it may also be noted that $84.7 \%$ of respondents are male while $15.3 \%$ are female. While considering the income level, a majority of $67(44.7 \%)$ respondents had an annual income level of Rs.3,00,000 to Rs. $6,00,000$, followed by $32 \%$ of respondents having annual income level below Rs.3,00,000. In so far as the educational background is concerned, Table 1 indicates that $48.7 \%$ of the respondents were graduates, $44 \%$ were post graduates and $7.3 \%$ of respondents held professional degree. Coming to the aspect of category of employees, most of the respondents represent 'Agents' category followed by managers and senior officers. If we talk of length of their service, bulk of them have the experience of 10-20 years which are closely followed by 5-10 year of service in the organisation.

Every important element of HRM (such as selection and recruitment, training, evaluation, promotion etc.) that plays a significant role in improving and maintaining viable relations between the employee and employer has been considered for study. The inferences regarding the same have been tabulated below where level of agreement using a Likert scale (from strongly disagree, disagree, undecided, agree and strongly agree as $1,2,3,4,5)$ is shown for every statement. Not limited to this, they have vital role in improving the financial health and credit worthiness of the organisation.

\subsection{Selection and recruitment}

The importance of selection needs no emphasis. Nevertheless it is gaining mounting recognition in human resources strategy, mainly in companies/firms everyplace where the continuation of bendable work systems giving satisfactory result. The efficiency of selection procedure is judged depending upon the equality, expenditure, openness, satisfactoriness (both to the applicant as well as the organisation), legitimacy and dependability, and applicability. Selection as a procedure does not subsist in space. It therefore, indicates that the selection procedure needs to be held as important work which is impacted more across-the-board atmosphere. Taking clue from this backdrop an attempt has been made as to examine the practices of selection procedures in the select units (Table 2). The wide-ranging system as plasticised by the companies/firms begins with the study of the bio data of the aspiring candidate and finishes with the becoming accustomed of the employee with the organisation, with certain exceptions in a few cases, for reasons best known to them. 
Table 2: Level of Agreement for Selection and Recruitment Statements

\begin{tabular}{|c|c|c|c|c|c|c|c|}
\hline \multirow{2}{*}{$\begin{array}{c}\text { Selection and } \\
\text { Recruitment Statements } \\
\end{array}$} & \multicolumn{6}{|c|}{ Level of Agreement } & \multirow[t]{2}{*}{ Total } \\
\hline & & 1 & 2 & 3 & 4 & 5 & \\
\hline \multirow{3}{*}{$\begin{array}{l}\text { Candidates are fully } \\
\text { informed about the } \\
\text { qualifications required to } \\
\text { perform the job before } \\
\text { being hired }\end{array}$} & No. & 4 & 12 & 43 & 67 & 24 & 150 \\
\hline & $\%$ of 150 & 2.67 & 8.00 & 28.67 & 44.67 & 16 & 100 \\
\hline & $\begin{array}{r}\% \text { of } \\
\text { GT(1350) }\end{array}$ & 0.30 & 0.89 & 3.19 & 4.96 & 1.78 & 11.11 \\
\hline \multirow{3}{*}{$\begin{array}{l}\text { Candidates for this job take } \\
\text { formal test (written or work } \\
\text { sample) for selecting } \\
\text { candidates for vacancies }\end{array}$} & No. & 2 & 7 & 21 & 78 & 42 & 150 \\
\hline & $\%$ of 150 & 1.33 & 4.67 & 14 & 52 & 28 & 100 \\
\hline & $\begin{array}{r}\% \text { of } \\
\text { GT(1350) }\end{array}$ & 0.15 & 0.52 & 1.56 & 5.78 & 3.11 & 11.11 \\
\hline \multirow{3}{*}{$\begin{array}{l}\text { Candidates undergo a } \\
\text { medical test before being } \\
\text { hired. }\end{array}$} & No. & 21 & 47 & 56 & 19 & 7 & 150 \\
\hline & $\%$ of 150 & 14 & 31.33 & 37.33 & 12.67 & 4.67 & 100 \\
\hline & $\begin{array}{r}\% \text { of } \\
\text { GT(1350) }\end{array}$ & 1.56 & 3.48 & 4.15 & 1.41 & 0.52 & 11.11 \\
\hline \multirow{3}{*}{$\begin{array}{l}\text { Candidates undergo } \\
\text { structured interviews (job } \\
\text { related questions, same } \\
\text { questions asked of all } \\
\text { applications) before being } \\
\text { hired }\end{array}$} & No. & 7 & 4 & 10 & 82 & 47 & 150 \\
\hline & $\%$ of 150 & 4.67 & 2.67 & 6.67 & 54.67 & 31.33 & 100 \\
\hline & $\begin{array}{r}\% \text { of } \\
\text { GT(1350) }\end{array}$ & 0.5 & 0.3 & 0.7 & 6.1 & 3.5 & 11.1 \\
\hline \multirow{3}{*}{$\begin{array}{l}\text { In this organisation, there is } \\
\text { formal induction, } \\
\text { orientation and } \\
\text { familiarization procedure } \\
\text { designed to help the new } \\
\text { managerial recruits } \\
\text { understand the organisation }\end{array}$} & No. & 11 & 24 & 25 & 73 & 17 & 150 \\
\hline & $\%$ of 150 & 7.33 & 16.00 & 16.67 & 48.67 & 11.33 & 100 \\
\hline & $\begin{array}{r}\% \text { of } \\
\text { GT(1350) }\end{array}$ & 0.81 & 1.78 & 1.85 & 5.41 & 1.26 & 11.11 \\
\hline \multirow{3}{*}{$\begin{array}{l}\text { Job advertisements in } \\
\text { newspapers are used by the } \\
\text { company to recruit people. }\end{array}$} & No. & 27 & 43 & 21 & 37 & 22 & 150 \\
\hline & $\%$ of 150 & 18 & 28.67 & 14.00 & 24.67 & 14.67 & 100 \\
\hline & $\begin{array}{r}\% \text { of } \\
\text { GT(1350) }\end{array}$ & 2 & 3.19 & 1.56 & 2.74 & 1.63 & 11.11 \\
\hline \multirow{3}{*}{$\begin{array}{l}\text { Selection system in our } \\
\text { organisation selects those } \\
\text { having the desired } \\
\text { knowledge and skills and } \\
\text { attitudes }\end{array}$} & No. & 31 & 27 & 39 & 21 & 32 & 150 \\
\hline & $\%$ of 150 & 20.67 & 18.00 & 26.00 & 14.00 & 21.33 & $\begin{array}{c}100.0 \\
0\end{array}$ \\
\hline & $\begin{array}{r}\% \text { of } \\
\text { GT(1350) }\end{array}$ & 2.30 & 2.00 & 2.89 & 1.56 & 2.37 & 11.11 \\
\hline
\end{tabular}




\begin{tabular}{|c|c|c|c|c|c|c|c|}
\hline \multirow{3}{*}{$\begin{array}{l}\text { The selection systems } \\
\text { followed in our } \\
\text { organisation are highly } \\
\text { scientific and rigorous. }\end{array}$} & No. & 37 & 56 & 32 & 9 & 16 & 150 \\
\hline & $\%$ of 150 & 24.67 & 37.33 & 21.33 & 6.00 & 10.67 & $\begin{array}{c}100.0 \\
0\end{array}$ \\
\hline & $\begin{array}{r}\% \text { of } \\
\text { GT(1350) }\end{array}$ & 2.74 & 4.15 & 2.37 & 0.67 & 1.19 & 11.11 \\
\hline \multirow{3}{*}{$\begin{array}{l}\text { Vacancies are filled from } \\
\text { qualified employees who } \\
\text { are working in the } \\
\text { organisation. }\end{array}$} & No. & 3 & 15 & 46 & 62 & 24 & 150 \\
\hline & $\%$ of 150 & 2 & 10 & 30.67 & 41.33 & 16 & 100 \\
\hline & $\begin{array}{r}\% \text { of } \\
\text { GT(1350) }\end{array}$ & 0.22 & 1.11 & 3.41 & 4.59 & 1.78 & 11.11 \\
\hline \multirow{2}{*}{$\begin{array}{l}\text { Grand Total }(\mathrm{GT}) \text { of } \\
\text { responses in all statements } \\
1350\end{array}$} & No. & 143 & 235 & 293 & 448 & 231 & 1350 \\
\hline & $\begin{array}{r}\% \text { of } \\
\text { GT(1350) }\end{array}$ & 10.6 & 17.4 & 21.7 & 33.2 & 17.1 & 100 \\
\hline
\end{tabular}

It may be observed from Table 2 that $41.33 \%$ of the employees viewed that the vacancies are filled up from eligible candidates who are already working in the company. This leads us to infer that less number of companies practice internal recruitment practices efficiently and depend on the external sources of employment to fill the gap in the human resources. The system of internal recruitment has its advantages and disadvantages and is mingled up with the issues of promotion and 'one and the same opportunities for all'. Any vacancy falling in an organisation provides an occasion for promotion within, mainly in times of flattening the hierarchies and a little opportunity to move up the organisation stepladder. Hence, equilibrium has to be maintained between recruiting the candidates most appropriate to embrace the position that satisfy the potential human resources and averting the perception of gaunt expenditure and time for exterior recruitment crusade.

A large number of methods are available to get in touch with the prospective candidate/s and to magnetize talent into the companies/firms, including union referrals, private consultants, colleges, universities, Government training institutes, advertising through print and electronic media, social networking web sites such as linked in, face book, twitter etc. The table depicts that merely $24.67 \%$ of the employees favoured the idea that the companies/firms are utilizing the potential ways and means of pulling the talents in to the organisation. Hence a bigger stress is necessary on the requirement for elasticity that can counteract with the time and cost in adopting the justly method of recruitment procedure among several ways and means of reaching the potential talent. 
The importance of the interview is to make available the organisation with an occasion to validate and complement a great deal of the information compiled with the help of other sources and to do away with any doubts about the data. Hence a selection procedure is considered as an essential ingredient of the employment procedure. Table 2 reveals that $44.67 \%$ of employees have the notion that the candidates are well aware about the qualifications required to perform the job prior to their hiring, whereas $52 \%$ of employees fills the vacancies by passing the formal test succeeded by structured interviews (54.67 \%) and followed by a medical test before being hired (37.33\%). A most important area of drive in the present companies/firms is to make known with the organisation policies and job related issues for the employees is the formal introduction, orientation and familiarization procedure which is being adopted in the select companies/firms as thought by $48.67 \%$ of employees and $37.33 \%$ of employees guessed that the selection systems in the select companies/firms are vastly scientific and stringent. The overall judgment over the selection and recruitment practices are held depending on selecting the appropriate candidate fulfilling the condition of preferred acquaintance, skill and attitude and it is manifested in select companies/firms (26\%).

From the above discussion, it is evident that more or less one third of the employees who are employed in select companies/firms are of the opinion that a there is no prescribed procedure for recruitment and selection in most organisations which is further corroborated by the job differential coefficient based on the technical as well as non-technical specifications.

\subsection{Training and development}

With all the latest technology in machinery, best quality ingredient or the money itself is of little use unless the organisation is well equipped with appropriate manpower. In other words, human resources are the priceless assets of any organisation. The time and money spent on staff training and development can make a very momentous contribution to the overall success and profitability of any organisation. Well-designed training modules provide employees with the specific skills or knowledge to set right the accessible deficiencies in the performance. There is definite doctrine that companies/firms have to follow to make sure that training modules provide required modifications in the work culture. Training modules need to be structured or designed keeping in view the functioning of organisation, management systems, and career expansion initiatives. Training systems need to be arranged considering well defined link to workplace outcomes. In cases where training is arranged as a reward, or its objectives are not specific or are unclear to all concerned, there I every likelihood that it may be a waste of time, money and resources. In contrast, where the training programmes are such 
that contributes value, has three significant elements, planning, organising the programme and follow up mechanism. The effectiveness of the training and development programme is realised stressing on the execution of these three elements. Hence, an attempt has been made to grasp the potency of training programme in the select companies/firms. With the intention of collecting the basis of inferences, the respondents' opinions are arranged in Table 3. The data can be classified into three families, (i), identification of training need and planning accordingly; (ii) implementing the training or development activity; and (iii), evaluation of training and development activity according to transmit of awareness and organise the employees to go well with the current and prospective challenges.

Table 3: Level of Agreement for Training and Development Statements

\begin{tabular}{|c|c|c|c|c|c|c|c|}
\hline \multirow{2}{*}{$\begin{array}{c}\text { Training and } \\
\text { Development } \\
\text { Statements }\end{array}$} & & \multicolumn{5}{|c|}{ Level of Agreement } & \multirow[t]{2}{*}{ Total } \\
\hline & & 1 & 2 & 3 & 4 & 5 & \\
\hline \multirow{3}{*}{$\begin{array}{l}\text { Efficiency in dealing } \\
\text { with problems } \\
\text { involving human } \\
\text { relations. }\end{array}$} & No. & 12 & 29 & 39 & 33 & 37 & 150 \\
\hline & $\%$ of 150 & 8 & 19.33 & 26 & 22 & 24.67 & 100 \\
\hline & $\begin{array}{r}\% \text { of } \\
\operatorname{GT}(1350)\end{array}$ & 0.62 & 1.49 & 2.00 & 1.69 & 1.90 & 7.69 \\
\hline \multirow{3}{*}{$\begin{array}{l}\text { I feel better equipped to } \\
\text { tackle unexpected } \\
\text { events with skill and } \\
\text { confidence. }\end{array}$} & No. & 5 & 13 & 44 & 68 & 20 & 150 \\
\hline & $\%$ of 150 & 3.33 & 8.67 & 29.33 & 45.33 & 13.33 & 100 \\
\hline & $\begin{array}{r}\% \text { of } \\
\text { GT(1350) }\end{array}$ & 0.26 & 0.67 & 2.26 & 3.49 & 1.03 & 7.69 \\
\hline \multirow{3}{*}{$\begin{array}{l}\text { I feel more confident } \\
\text { and better equipped to } \\
\text { act as a leader and } \\
\text { handle conflicting } \\
\text { situations. }\end{array}$} & No. & 7 & 12 & 49 & 61 & 21 & 150 \\
\hline & $\%$ of 150 & 4.67 & 8.00 & 32.67 & 40.67 & 14.00 & 100 \\
\hline & $\begin{array}{r}\% \text { of } \\
\text { GT(1350) }\end{array}$ & 0.36 & 0.62 & 2.51 & 3.13 & 1.08 & 7.69 \\
\hline \multirow{3}{*}{$\begin{array}{l}\text { I have training } \\
\text { opportunities to learn } \\
\text { and grow }\end{array}$} & No. & 10 & 23 & 28 & 34 & 55 & 150 \\
\hline & $\%$ of 150 & 6.67 & 15.33 & 18.67 & 22.67 & 36.67 & 100.00 \\
\hline & $\begin{array}{r}\% \text { of } \\
\text { GT(1350) }\end{array}$ & 0.51 & 1.18 & 1.44 & 1.74 & 2.82 & 7.69 \\
\hline \multirow{3}{*}{$\begin{array}{l}\text { My working } \\
\text { relationship between } \\
\text { my associates and } \\
\text { colleagues in other } \\
\text { departments has } \\
\text { improved. }\end{array}$} & No. & 17 & 14 & 64 & 31 & 24 & 150 \\
\hline & $\%$ of 150 & 11.33 & 9.33 & 42.67 & 20.67 & 16.00 & 100.00 \\
\hline & $\begin{array}{r}\% \text { of } \\
\text { GT(1350) }\end{array}$ & 0.87 & 0.72 & 3.28 & 1.59 & 1.23 & 7.69 \\
\hline
\end{tabular}




\begin{tabular}{|c|c|c|c|c|c|c|c|}
\hline \multirow{3}{*}{$\begin{array}{l}\text { Number of decisions } \\
\text { taken without referring } \\
\text { to higher authorities. }\end{array}$} & No. & 4 & 12 & 31 & 69 & 34 & 150 \\
\hline & $\%$ of 150 & 2.67 & 8.00 & 20.67 & 46.00 & 22.67 & 100.00 \\
\hline & $\begin{array}{r}\% \text { of } \\
\text { GT(1350) }\end{array}$ & 0.21 & 0.62 & 1.59 & 3.54 & 1.74 & 7.69 \\
\hline \multirow{3}{*}{$\begin{array}{l}\text { Our organisation } \\
\text { conducts extensive } \\
\text { training programs for } \\
\text { its employees in all } \\
\text { aspects of quality. }\end{array}$} & No. & 34 & 41 & 47 & 23 & 5 & 150 \\
\hline & $\%$ of 150 & 22.67 & 27.33 & 31.33 & 15.33 & 3.33 & 100.00 \\
\hline & $\begin{array}{r}\% \text { of } \\
\text { GT(1350) }\end{array}$ & 1.74 & 2.10 & 2.41 & 1.18 & 0.26 & 7.69 \\
\hline \multirow{3}{*}{$\begin{array}{l}\text { Sent for the training as } \\
\text { a ticket for promotional } \\
\text { purposes. }\end{array}$} & No. & 11 & 19 & 37 & 41 & 42 & 150 \\
\hline & $\%$ of 150 & 7.33 & 12.67 & 24.67 & 27.33 & 28.00 & 100.00 \\
\hline & $\begin{array}{r}\% \text { of } \\
\text { GT(1350) }\end{array}$ & 0.56 & 0.97 & 1.90 & 2.10 & 2.15 & 7.69 \\
\hline \multirow{3}{*}{$\begin{array}{l}\text { The objective of the } \\
\text { training programmes is } \\
\text { complete understanding } \\
\text { of diverse management } \\
\text { functions in its totality }\end{array}$} & No. & 7 & 16 & 32 & 67 & 28 & 150 \\
\hline & $\%$ of 150 & 4.67 & 10.67 & 21.33 & 44.67 & 18.67 & 100.00 \\
\hline & $\begin{array}{r}\% \text { of } \\
\text { GT(1350) }\end{array}$ & 0.36 & 0.82 & 1.64 & 3.44 & 1.44 & 7.69 \\
\hline \multirow{3}{*}{$\begin{array}{l}\text { The training } \\
\text { programmes has } \\
\text { improved my decision- } \\
\text { making skills }\end{array}$} & No. & 9 & 14 & 37 & 54 & 36 & 150 \\
\hline & $\%$ of 150 & 6 & 9.33 & 24.67 & 36 & 24 & 100 \\
\hline & $\begin{array}{r}\% \text { of } \\
\text { GT(1350) }\end{array}$ & 0.46 & 0.72 & 1.90 & 2.77 & 1.85 & 7.69 \\
\hline \multirow{3}{*}{$\begin{array}{l}\text { Training needs are } \\
\text { identified through a } \\
\text { formal functioning } \\
\text { appraisal mechanism. }\end{array}$} & No. & 23 & 39 & 32 & 37 & 19 & 150 \\
\hline & $\%$ of 150 & 15.33 & 26.00 & 21.33 & 24.67 & 12.67 & 100.00 \\
\hline & $\begin{array}{r}\% \text { of } \\
\text { GT(1350) }\end{array}$ & 1.18 & 2.00 & 1.64 & 1.90 & 0.97 & 7.69 \\
\hline \multirow{3}{*}{$\begin{array}{l}\text { Training needs } \\
\text { identified are realistic, } \\
\text { useful and based on the } \\
\text { business strategy of the } \\
\text { organisation }\end{array}$} & No. & 49 & 32 & 20 & 25 & 24 & 150 \\
\hline & $\%$ of 150 & 32.67 & 21.33 & 13.33 & 16.67 & 16.00 & 100.00 \\
\hline & $\begin{array}{r}\% \text { of } \\
\text { GT(1350) }\end{array}$ & 2.51 & 1.64 & 1.03 & 1.28 & 1.23 & 7.69 \\
\hline \multirow{3}{*}{$\begin{array}{l}\text { Was selected because } \\
\text { the programme } \\
\text { objectives suit my job } \\
\text { needs most. }\end{array}$} & No. & 34 & 57 & 28 & 14 & 17 & 150 \\
\hline & $\%$ of 150 & 22.67 & 38.00 & 18.67 & 9.33 & 11.33 & 100.00 \\
\hline & $\begin{array}{r}\% \text { of } \\
\text { GT(1350) }\end{array}$ & 1.74 & 2.92 & 1.44 & 0.72 & 0.87 & 7.69 \\
\hline \multirow{2}{*}{$\begin{array}{l}\text { Grand Total (GT) of } \\
\text { responses in all } \\
\text { statements } 1350\end{array}$} & No. & 222 & 321 & 488 & 557 & 362 & 1950 \\
\hline & $\begin{array}{r}\% \text { of } \\
\text { GT(1350) }\end{array}$ & 11.38 & 16.46 & 25.03 & 28.56 & 18.56 & 100.00 \\
\hline
\end{tabular}

Source: Author's own 
In majority of establishments, a training programme is framed considering its utility to resolve the identified problem areas. Before initiating steps to introduce a training programme it is necessary to make a detailed study of functioning of concerned organisation, its various operations and man power resources available in order to locate the problem area/s where training may be necessitated. The details embodied in Table 3 indicates that $24.67 \%$ of respondents agree that the requirements of training programme are named by a formal operating assessment mechanism while $16.67 \%$ of the respondents are of the view that named requirements are realistic, helpful and are in harmony with the business policy. The replies as forwarded by the respondents towards the acknowledged training requirements are in tune with the business policy and it is evidently indicates that the programmes objectives fit the job requirements of the respondents. The details embodied in the table are pointer that significant number of the employees i.e. $38 \%$ of the employees did not accord that they were opted the training programme as it befit the job requirement although the aims of the training programme tender absolute understanding of the management concerns as thought by $44.67 \%$ of employees. It is therefore, concluded that training objectives needs to be rational, helpful and based on the business policy apart they have to be known all the way through a proper functioning evaluation mechanism as opined by the $16.67 \%$ and $24.67 \%$ of employees. The table also indicates that $44.67 \%$ of employees' favour that the training programmes need to be organized that wrap all the aspects of the quality.

\subsection{Functioning evaluation}

Functioning management systems are inbuilt component of majority of the companies/firms. Appropriately formulated and carried out functioning management procedures do help an organisation in accomplishing its objectives by formulating fertile employees. The assessment procedure shapes a significant section of the functioning management system which forms several phases. The appraisal process commences with the administration of functioning measures in accordance with the companies/firms strategic objectives. After establishing functioning values, it is obligatory to transmit these outlooks and decide the right meaning of actual functioning. In the absence of proper comparison of actual functioning with the standards and proper communication of the same, they will be irrelevant. Table 4 is indicative of the fact that $39 \%$ of respondents favour that plainly defined aims of the appraisal method in the companies/firms remain in harmony with the growth and improvement schemes of the organisation and they are made known to all the employees in the form of letter/notification $(25.0 \%)$. Here it is essential to mention that all functioning appraisal procedure and technique need to be free from personal prejudices. $29.2 \%$ of respondents were of the opinion that the 
functioning appraisal remains on the premise that objectivity reduces possible discretional and non-adaptive behaviours by the raters.

Table 4: Level of Agreement for Functioning Evaluation

\begin{tabular}{|c|c|c|c|c|c|c|c|}
\hline \multirow{2}{*}{$\begin{array}{c}\text { Functioning } \\
\text { Evaluation }\end{array}$} & & \multicolumn{5}{|c|}{ Level of Agreement } & \multirow[t]{2}{*}{ Total } \\
\hline & & 1 & 2 & 3 & 4 & 5 & \\
\hline \multirow{3}{*}{$\begin{array}{l}\text { Appraisal system has a } \\
\text { strong influence on } \\
\text { individual and team } \\
\text { behavior. }\end{array}$} & No. & 16 & 39 & 18 & 55 & 22 & 150 \\
\hline & $\%$ of 150 & 10.4 & 26.3 & 12.1 & 36.7 & 14.5 & 100 \\
\hline & $\begin{array}{r}\% \text { of } \\
\text { GT(1350) }\end{array}$ & 1 & 3 & 1 & 4 & 1 & 10 \\
\hline \multirow{3}{*}{$\begin{array}{l}\text { Appraisal system in } \\
\text { our organisation is } \\
\text { growth and } \\
\text { development oriented. }\end{array}$} & No. & 18 & 39 & 12 & 59 & 22 & 150 \\
\hline & $\%$ of 150 & 12.1 & 25.9 & 8.1 & 39 & 14.9 & 100 \\
\hline & $\begin{array}{r}\% \text { of } \\
\text { GT(1350) }\end{array}$ & 1 & 3 & 1 & 4 & 1 & 10 \\
\hline \multirow{3}{*}{$\begin{array}{l}\text { Employees are } \\
\text { provided functioning } \\
\text { based feedback and } \\
\text { counseling. }\end{array}$} & No. & 54 & 20 & 9 & 42 & 26 & 150 \\
\hline & $\%$ of 150 & 36.1 & 13.1 & 5.8 & 28 & 17 & 100 \\
\hline & $\begin{array}{r}\% \text { of } \\
\text { GT(1350) }\end{array}$ & 4 & 1 & 1 & 3 & 2 & 10 \\
\hline \multirow{3}{*}{$\begin{array}{l}\text { I am informed that } \\
\text { how my functioning is } \\
\text { evaluated }\end{array}$} & No. & 30 & 24 & 21 & 48 & 28 & 150 \\
\hline & $\%$ of 150 & 20 & 16 & 13.8 & 31.8 & 18.4 & 100 \\
\hline & $\begin{array}{r}\% \text { of } \\
\text { GT(1350) }\end{array}$ & 2 & 2 & 1 & 3 & 2 & 10 \\
\hline \multirow{3}{*}{$\begin{array}{l}\text { I receive feedback of } \\
\text { functioning evaluation } \\
\text { results about myself. }\end{array}$} & No. & 25 & 46 & 18 & 40 & 22 & 150 \\
\hline & $\%$ of 150 & 16.4 & 30.4 & 12.1 & 26.5 & 14.6 & 100 \\
\hline & $\begin{array}{r}\% \text { of } \\
\text { GT(1350) }\end{array}$ & 2 & 3 & 1 & 3 & 1 & 10 \\
\hline \multirow{3}{*}{$\begin{array}{l}\text { Functioning of the } \\
\text { employees is measured } \\
\text { on the basis of } \\
\text { objective quantifiable } \\
\text { results. }\end{array}$} & No. & 28 & 36 & 22 & 44 & 19 & 150 \\
\hline & $\%$ of 150 & 18.9 & 24.2 & 14.8 & 29.2 & 12.9 & 100 \\
\hline & $\begin{array}{r}\% \text { of } \\
\text { GT(1350) }\end{array}$ & 2 & 2 & 1 & 3 & 1 & 10 \\
\hline \multirow{3}{*}{$\begin{array}{l}\text { The appraisal data is } \\
\text { used for making } \\
\text { decisions like job } \\
\text { rotation, training and } \\
\text { compensation }\end{array}$} & No. & 35 & 21 & 16 & 59 & 18 & 150 \\
\hline & $\%$ of 150 & 23.4 & 14.3 & 10.9 & 39.1 & 12.3 & 100 \\
\hline & $\begin{array}{r}\% \text { of } \\
\text { GT(1350) }\end{array}$ & 2 & 1 & 1 & 4 & 1 & 10 \\
\hline
\end{tabular}




\begin{tabular}{|c|c|c|c|c|c|c|c|}
\hline \multirow{3}{*}{$\begin{array}{l}\text { The objectives of the } \\
\text { appraisal system are } \\
\text { clear to all employees. }\end{array}$} & No. & 18 & 36 & 16 & 59 & 21 & 150 \\
\hline & $\%$ of 150 & 12.3 & 24 & 10.8 & 39 & 13.9 & 100 \\
\hline & $\begin{array}{r}\% \text { of } \\
\text { GT(1350) }\end{array}$ & 1 & 2 & 1 & 4 & 1 & 10 \\
\hline \multirow{3}{*}{$\begin{array}{l}\text { The functioning } \\
\text { appraisal is fair. }\end{array}$} & No. & 44 & 21 & 33 & 37 & 15 & 150 \\
\hline & $\%$ of 150 & 29.2 & 14.1 & 21.9 & 24.8 & 10 & 100 \\
\hline & $\begin{array}{r}\% \text { of } \\
\text { GT(1350) }\end{array}$ & 3 & 1 & 2 & 2 & 1 & 10 \\
\hline \multirow{3}{*}{$\begin{array}{l}\text { There is a formal \& } \\
\text { written functioning } \\
\text { Appraisal system. }\end{array}$} & No. & 27 & 40 & 23 & 39 & 21 & 150 \\
\hline & $\%$ of 150 & 17.8 & 26.7 & 15.4 & 25.8 & 14.3 & 100 \\
\hline & $\begin{array}{r}\% \text { of } \\
\text { GT(1350) }\end{array}$ & 2 & 3 & 2 & 3 & 1 & 10 \\
\hline \multirow{2}{*}{$\begin{array}{l}\text { Grand Total (GT) of } \\
\text { responses in all } \\
\text { statements } 1350\end{array}$} & No. & 295 & 323 & 189 & 480 & 214 & 1500 \\
\hline & $\begin{array}{r}\% \text { of } \\
\text { GT(1350) }\end{array}$ & 20 & 22 & 13 & 32 & 14 & 100 \\
\hline
\end{tabular}

Source: Author's own

After the appraisal, the raters must discuss keeping in view the functioning, aims and objectives with the rates, to obtain proper feedback to evaluation more purposefully and their ranking in the eyes of the management. This kind of feedback shall go a long way to bring improvement in performance, more so when it is short of expectation. Further, Table 4 points out that $31.8 \%$ of the respondents affirmed that they are conversant with their functioning that is evaluated but $28.0 \%$ of them reacted otherwise. Opposite to this view it is observed that $26.5 \%$ of respondents received feedback on their own. In this scenario, there is strong case for improving the management functioning system to develop a suitable approach to provide the raters with the prospect to join in healthy discussion and set up a purposeful discussion.

The role of HR manager becomes more crucial as he must prepare database of appraisal details to win over the employee concerned in a situation like difference of opinion on vital issues such as promotion, pay hike, confirmation of probationary services etc. Table 4 provides evidence to show that $39.1 \%$ of respondents are confident with the determinations such as job rotation, training and compensation rendered by the organisation keeping in view the functioning appraisal. The table also discloses that $36.7 \%$ of employees feel that the appraisal system sways the individual and team behaviours. To conclude, it is revealed that $25 \%$ of the employees sensed that the functioning system is just and reasonable in the select units. 


\subsection{Promotion policy}

It is important to know that the promotion policy is an extremely delicate matter, and if it is unfair, unjust, biased or leaves scope for favouritism, it may lead to unhappiness, dissatisfaction, uncertainty and bickering among the employees, and results in a high rate of turnover. There must be equitable and clear policy to fill up higher positions by internal promotions or recruit people from outside. Fair and equitable policy on promotion contributes to employee contentment and enthusiasm. The survey responses pertaining to the promotion policy in select insurance industries are embodied in Table 5.

Table 5: Level of Agreement for Promotion Policy

\begin{tabular}{|c|c|c|c|c|c|c|c|}
\hline \multirow[t]{2}{*}{ Promotion Policy } & & \multicolumn{5}{|c|}{ Level of Agreement } & \multirow[t]{2}{*}{ Total } \\
\hline & & 1 & 2 & 3 & 4 & 5 & \\
\hline \multirow{3}{*}{$\begin{array}{l}\text { Company has a } \\
\text { written promotion } \\
\text { policy }\end{array}$} & No. & 29 & 43 & 21 & 37 & 20 & 150 \\
\hline & $\%$ of 150 & 19.6 & 28.5 & 13.8 & 24.6 & 13.5 & 100 \\
\hline & $\begin{array}{r}\% \text { of } \\
\text { GT(1350) }\end{array}$ & 5 & 7 & 3 & 6 & 3 & 25 \\
\hline \multirow{3}{*}{$\begin{array}{l}\text { Job promotions are } \\
\text { fair and equitable }\end{array}$} & No. & 17 & 29 & 20 & 59 & 25 & 150 \\
\hline & $\%$ of 150 & 11.2 & 19.2 & 13.4 & 39.4 & 16.8 & 100 \\
\hline & $\begin{array}{r}\% \text { of } \\
\text { GT(1350) }\end{array}$ & 3 & 5 & 3 & 10 & 4 & 25 \\
\hline \multirow{3}{*}{$\begin{array}{l}\text { Priority is given } \\
\text { for seniority in } \\
\text { promotion decision }\end{array}$} & No. & 22 & 21 & 19 & 65 & 23 & 150 \\
\hline & $\%$ of 150 & 14.9 & 14.1 & 12.4 & 43.2 & 15.4 & 100 \\
\hline & $\begin{array}{r}\% \text { of } \\
\text { GT(1350) }\end{array}$ & 4 & 4 & 3 & 11 & 4 & 25 \\
\hline \multirow{3}{*}{$\begin{array}{l}\text { Priority is given } \\
\text { for merit in } \\
\text { promotion } \\
\text { decisions }\end{array}$} & No. & 18 & 26 & 21 & 53 & 31 & 150 \\
\hline & $\%$ of 150 & 12.1 & 17.6 & 14.2 & 35.2 & 20.9 & 100 \\
\hline & $\begin{array}{r}\% \text { of } \\
\text { GT(1350) }\end{array}$ & 3 & 4 & 4 & 9 & 5 & 25 \\
\hline \multirow{2}{*}{$\begin{array}{l}\text { Grand Total }(\mathrm{GT}) \\
\text { of responses in all } \\
\text { statements } 1350\end{array}$} & No. & 87 & 119 & 81 & 214 & 100 & 600 \\
\hline & $\begin{array}{r}\% \text { of } \\
\text { GT(1350) }\end{array}$ & 14 & 20 & 13 & 36 & 17 & 100 \\
\hline
\end{tabular}

Source: Author's own

Table 5 clearly helps us to understand that barely $24.6 \%$ of respondents are happy to affirm that select insurance units maintains a unequivocal and laid down policy while $39.4 \%$ of respondents alleged that the promotions in the select units are fair and 
equitable. From the above, it can be inferred that a clear and distinctive written policy is framed to create an environment in the companies/firms that could provide fair and equitable job promotions to the employees. In so far as the promotions are concerned it may also be seen from the Table that $43.2 \%$ of employees suppose that preference is given for the seniority whereas $35.2 \%$ of are of the view that merit take precedence over seniority. Usually in almost all organisations, especially government owned, seniority plays a key role in the matter of promotions. Nevertheless, in the select insurance units, promotions are determined by the trade unions or policies of the companies/firms on one hand, and put forward just and unbiased share of promotions, on the other hand.

\subsection{Dealing the grievances}

Grievances developed in the brain of individual employee, are developed or degenerated by the situations. They are either furthered or cured by group forces, or are corrected or made worse by supervisors, and are nurtured or resolved by the environment in the unit which is accomplished by various factors mentioned herein as well as by the management. Generally prime reasons for employees' grievances could be due to promotion, facilities, continuity of service, compensation, disciplinary action, fine, increment, leave, medical benefit, job profile etc. A positive move for redressal of grievances assists the management to initiate corrective measures for those factors that cause rise of grievances. A study was undertaken to examine the grievance dealing methods in the select insurance units, and the result is given in Table 6. The figures in the Table show that $55.8 \%$ and $40.7 \%$ of employees in select insurance units have the notion that their immediate superiors are able to deal the work linked elements which includes facilities, payment, job profile and working conditions suitably and the allocation of the work is done in an efficient way. This goes to indicate that the grievances take place majorly owing to the work related issues and can be resolved at the grass root level. Matters relating to supervision like poor relations with supervisor, unreadable and undefined job concerning instructions, though looks tiny but sometimes lead to the turmoil in the establishment and insurance sector is no exception to this.

It can also be noted that $40.3 \%$ of employees agree that the supervisor could be good enough to render most needed guidance and directions. This kind of atmosphere in the sector when exist indicates that tone of supervision and work related matters are in agreement with the unit' demands that paves the way for minimising the degree of grievances of the employees. In addition it is a pointer to the fact that the select insurance industries have built-in systems to deal with grievances, if any, effectively, as felt by $45.0 \%$ of employees. Hence, the outcome of the above analysis is that the 'Grievance Dealing Systems' in the select insurance industries are reasonably efficient to 
resolve grievances. Further, the employees of the select insurance industries have sufficient trust in the grievance procedure laid down in the selected industries.

Table 6: Level of Agreement for Grievance Handling-Procedure Level

\begin{tabular}{|c|c|c|c|c|c|c|c|}
\hline \multirow{2}{*}{$\begin{array}{c}\text { Grievance handling- } \\
\text { procedure level }\end{array}$} & & \multicolumn{5}{|c|}{ Level of Agreement } & \multirow[t]{2}{*}{ Total } \\
\hline & & 1 & 2 & 3 & 4 & 5 & \\
\hline \multirow{3}{*}{$\begin{array}{l}\text { My supervisor } \\
\text { delegates work } \\
\text { effectively }\end{array}$} & No. & 20 & 31 & 19 & 61 & 19 & 150 \\
\hline & $\%$ of 150 & 13.6 & 20.5 & 12.5 & 40.7 & 12.7 & 100 \\
\hline & $\begin{array}{r}\% \text { of } \\
\text { GT(1350) }\end{array}$ & 3 & 5 & 3 & 10 & 3 & 25 \\
\hline \multirow{3}{*}{$\begin{array}{l}\text { My supervisor handles } \\
\text { my work related issues } \\
\text { satisfactorily }\end{array}$} & No. & 10 & 20 & 11 & 84 & 26 & 150 \\
\hline & $\%$ of 150 & 6.6 & 13.4 & 7 & 55.8 & 17.2 & 100 \\
\hline & $\begin{array}{r}\% \text { of } \\
\text { GT(1350) }\end{array}$ & 2 & 3 & 2 & 14 & 4 & 25 \\
\hline \multirow{3}{*}{$\begin{array}{l}\text { My supervisor is } \\
\text { available to me when I } \\
\text { have questions or need } \\
\text { help }\end{array}$} & No. & 20 & 31 & 22 & 60 & 17 & 150 \\
\hline & $\%$ of 150 & 13.4 & 20.9 & 14.4 & 40.3 & 11 & 100 \\
\hline & $\begin{array}{r}\% \text { of } \\
\text { GT(1350) }\end{array}$ & 3 & 5 & 4 & 10 & 3 & 25 \\
\hline \multirow{3}{*}{$\begin{array}{l}\text { There are formal } \\
\text { procedures for handling } \\
\text { grievances }\end{array}$} & No. & 18 & 17 & 19 & 68 & 29 & 150 \\
\hline & $\%$ of 150 & 11.7 & 11.1 & 12.9 & 45 & 19.3 & 100 \\
\hline & $\begin{array}{r}\% \text { of } \\
\text { GT(1350) }\end{array}$ & 3 & 3 & 3 & 11 & 5 & 25 \\
\hline \multirow{2}{*}{$\begin{array}{l}\text { Grand Total (GT) of } \\
\text { responses in all } \\
\text { statements } 1350\end{array}$} & No. & 68 & 99 & 70 & 273 & 90 & 600 \\
\hline & $\begin{array}{r}\% \text { of } \\
\text { GT(1350) }\end{array}$ & 11 & 16 & 12 & 45 & 15 & 100 \\
\hline
\end{tabular}

Source: Author's own

\subsection{Career planning and development}

Individuals' career planning has acquired larger importance due to phenomenal growth in job opportunities. Further, this aspect acquired grandness with the improvement in technology, human needs, values and aspirations, increase in companies. Hence, work of career planning is managed by both employees and the company together. The outcome of the study in respect of this aspect is given in Table 7. The table indicates that barely $27.1 \%$ of the persons from select groups favour the companies' plans for the career and development of employees whereas $20.1 \%$ of respondents did not endorse this view. $40.4 \%$ of employees concur that they created consciousness about 
their career paths in the company that led to $37.4 \%$ of employees to have clear ways and to make concentrated efforts to by using a multiple self-development methods.

Table 7: Level of Agreement for Career Planning and Development

\begin{tabular}{|c|c|c|c|c|c|c|c|}
\hline \multirow{2}{*}{$\begin{array}{c}\text { CAREER PLANNING AND } \\
\text { DEVELOPMENT }\end{array}$} & & \multicolumn{5}{|c|}{ Level of Agreement } & \multirow[t]{2}{*}{ Total } \\
\hline & & 1 & 2 & 3 & 4 & 5 & \\
\hline \multirow{3}{*}{$\begin{array}{l}\text { Each employee is aware of } \\
\text { his/her career path in the } \\
\text { organisation. }\end{array}$} & No. & 16 & 43 & 17 & 61 & 14 & 150 \\
\hline & $\%$ of 150 & 10.4 & 28.5 & 11.4 & 40.4 & 9.3 & 100 \\
\hline & $\begin{array}{r}\% \text { of } \\
\text { GT(1350) }\end{array}$ & 1 & 4 & 2 & 6 & 1 & 14 \\
\hline \multirow{3}{*}{$\begin{array}{l}\text { Employee's career aspirations } \\
\text { within the organisation are } \\
\text { known by his/ her immediate } \\
\text { supervisor. }\end{array}$} & No. & 16 & 38 & 22 & 62 & 12 & 150 \\
\hline & $\%$ of 150 & 10.9 & 25 & 14.8 & 41.4 & 7.9 & 100 \\
\hline & $\begin{array}{r}\% \text { of } \\
\text { GT(1350) }\end{array}$ & 2 & 4 & 2 & 6 & 1 & 14 \\
\hline \multirow{3}{*}{$\begin{array}{l}\text { Employees in our organisation } \\
\text { have more than one potential } \\
\text { position for promotion. }\end{array}$} & No. & 32 & 19 & 15 & 66 & 18 & 150 \\
\hline & $\%$ of 150 & 21.4 & 12.9 & 9.7 & 44.3 & 11.7 & 100 \\
\hline & $\begin{array}{r}\% \text { of } \\
\text { GT(1350) }\end{array}$ & 3 & 2 & 1 & 6 & 2 & 14 \\
\hline \multirow{3}{*}{$\begin{array}{l}\text { Individual and organisation } \\
\text { growth needs are matched in } \\
\text { this organisation. }\end{array}$} & No. & 20 & 30 & 23 & 51 & 27 & 150 \\
\hline & $\%$ of 150 & 13 & 20.2 & 15.2 & 33.8 & 17.8 & 100 \\
\hline & $\begin{array}{r}\% \text { of } \\
\text { GT(1350) }\end{array}$ & 2 & 3 & 2 & 5 & 3 & 14 \\
\hline \multirow{3}{*}{$\begin{array}{l}\text { Individuals in this } \\
\text { organisation have clear career } \\
\text { paths. }\end{array}$} & No. & 24 & 26 & 26 & 56 & 18 & 150 \\
\hline & $\%$ of 150 & 16 & 17 & 17.3 & 37.4 & 12.3 & 100 \\
\hline & $\begin{array}{r}\% \text { of } \\
\text { GT(1350) }\end{array}$ & 2 & 2 & 2 & 5 & 2 & 14 \\
\hline \multirow{3}{*}{$\begin{array}{l}\text { Our organisation plans for the } \\
\text { career and development of } \\
\text { employees. }\end{array}$} & No. & 32 & 30 & 21 & 41 & 26 & 150 \\
\hline & $\%$ of 150 & 21.2 & 20.1 & 14.3 & 27.1 & 17.3 & 100 \\
\hline & $\begin{array}{r}\% \text { of } \\
\text { GT(1350) }\end{array}$ & 3 & 3 & 2 & 4 & 2 & 14 \\
\hline \multirow{3}{*}{$\begin{array}{l}\text { Our organisation prefers an } \\
\text { internal employee whenever a } \\
\text { vacancy exists. }\end{array}$} & No. & 25 & 25 & 20 & 54 & 27 & 150 \\
\hline & $\%$ of 150 & 16.5 & 16.4 & 13.4 & 35.7 & 18 & 100 \\
\hline & $\begin{array}{r}\% \text { of } \\
\text { GT(1350) }\end{array}$ & 2 & 2 & 2 & 5 & 3 & 14 \\
\hline \multirow{2}{*}{$\begin{array}{l}\text { Grand Total }(\mathrm{GT}) \text { of } \\
\text { responses in all statements } \\
1350\end{array}$} & No. & 164 & 210 & 144 & 390 & 141 & 1050 \\
\hline & $\begin{array}{r}\% \text { of } \\
\text { GT(1350) }\end{array}$ & 16 & 20 & 14 & 37 & 13 & 100 \\
\hline
\end{tabular}

Source: Author's own 
The responses given in Table 7 indicate that $41.4 \%$ and $33.8 \%$ of employees have the view that their wishes and aspirations are clearly conveyed to their immediate superiors and growth needs are coordinated correspondingly. Hence in this backdrop it can be inferred that the practice of the select units helps to improve the likelihood of getting the right people to meet with the changing human requirements. It is also clear that the select insurance units are doing well in their career planning and development as $44.3 \%$ and $35.7 \%$ of respondents have expressed that their company formed a possibility for probable positions for ladder promotions and internal employees are given the first choice to fill the opening if the personal and work requirements are met. Hence, the study indicates that the select insurance industries provide a clear match between personal and work requirements of the individuals and companies that assures to meet the employee' anticipations and the accessibility of the human resources with the expected skill, know-how and natural endowment.

\subsection{Job satisfaction}

It is needless to mention that level of job satisfaction differ from person to person despite the fact that the same job in the same job environment at the same time is performed. There are number of determinants that affects the level of job satisfaction such as degree and kind of education, age group, gender, social and family life, occupation level, level and type of supervision, promotion avenues; etc. The outcome of study in this area is given in Table 8. It is evident that majority i.e., $51.3 \%$ of the respondents are greatly satisfied with the pay they receive from the job whereas with minor difference i.e., $50.6 \%$ of respondents are immensely satisfied with the security of the job. $47.1 \%$ of respondents are highly satisfied with the consistent environment. $40.4 \%$ and $33.1 \%$ respectively hold the view that self-determining thought on the job front and the freedom to perform the job gave them great satisfaction. All this indicates that the jobs in insurance sector are so tailor made that they provide motivation, satisfaction and functioning corresponding to the nature of job. It is also perceived from the analysis that $44.7 \%$ and $45.2 \%$ of employees believe that their satisfaction level is linked with the kind of interaction with the supervisor about their functioning and the opportunities for ladder promotion respectively.

\subsection{Company commitment}

Company commitment is assessed in terms of the intensity of an individual's recognition with and participation in the organisation. When commitment is high, it means that an employee's values are aligned with the company and that the individual is eager to do what is valuable for the company. 
Table 8: Level of Agreement for Job Satisfaction Statement

\begin{tabular}{|c|c|c|c|c|c|c|c|}
\hline \multirow{2}{*}{$\begin{array}{c}\text { Job Satisfaction } \\
\text { Statement }\end{array}$} & & \multicolumn{5}{|c|}{ Level of Agreement } & \multirow[t]{2}{*}{ Total } \\
\hline & & 1 & 2 & 3 & 4 & 5 & \\
\hline \multirow{3}{*}{$\begin{array}{l}\text { I am satisfied with } \\
\text { the freedom I have } \\
\text { to do what I want on } \\
\text { my job. }\end{array}$} & No. & 24 & 31 & 20 & 50 & 26 & 150 \\
\hline & $\%$ of 150 & 15.7 & 20.4 & 13.6 & 33.1 & 17.2 & 100 \\
\hline & $\%$ of GT(1350) & 2 & 3 & 2 & 4 & 2 & 13 \\
\hline \multirow{3}{*}{$\begin{array}{l}\text { I am satisfied with } \\
\text { the information I } \\
\text { receive from my } \\
\text { supervisor about my } \\
\text { performance. }\end{array}$} & No. & 20 & 30 & 16 & 67 & 17 & 150 \\
\hline & $\%$ of 150 & 13.4 & 19.9 & 10.8 & 44.7 & 11.2 & 100 \\
\hline & $\%$ of GT(1350) & 2 & 2 & 1 & 6 & 1 & 13 \\
\hline \multirow{3}{*}{$\begin{array}{l}\text { I am satisfied with } \\
\text { the opportunities my } \\
\text { job gives to } \\
\text { complete the task } \\
\text { from beginning. }\end{array}$} & No. & 18 & 20 & 15 & 68 & 29 & 150 \\
\hline & $\%$ of 150 & 11.9 & 13.2 & 10.3 & 45.2 & 19.4 & 100 \\
\hline & $\%$ of GT(1350) & 1 & 2 & 1 & 6 & 2 & 13 \\
\hline \multirow{3}{*}{$\begin{array}{l}\text { I am satisfied with } \\
\text { the opportunities my } \\
\text { job provides me to } \\
\text { interact with others. }\end{array}$} & No. & 26 & 18 & 22 & 71 & 14 & 150 \\
\hline & $\%$ of 150 & 17 & 12.1 & 14.7 & 47.1 & 9.1 & 100 \\
\hline & $\%$ of GT(1350) & 2 & 2 & 2 & 6 & 1 & 13 \\
\hline \multirow{3}{*}{$\begin{array}{l}\text { I am satisfied with } \\
\text { the pay I receive for } \\
\text { my job. }\end{array}$} & No. & 23 & 17 & 18 & 77 & 15 & 150 \\
\hline & $\%$ of 150 & 15.3 & 11 & 12.2 & 51.3 & 10.2 & 100 \\
\hline & $\%$ of GT(1350) & 2 & 1 & 2 & 6 & 1 & 13 \\
\hline \multirow{3}{*}{$\begin{array}{l}\text { I am satisfied with } \\
\text { the security my job } \\
\text { provides me. }\end{array}$} & No. & 18 & 19 & 17 & 76 & 20 & 150 \\
\hline & $\%$ of 150 & 11.7 & 12.6 & 11.5 & 50.6 & 13.6 & 100 \\
\hline & $\%$ of GT(1350) & 1 & 2 & 1 & 6 & 2 & 13 \\
\hline \multirow{3}{*}{$\begin{array}{l}\text { I am satisfied with } \\
\text { the variety of } \\
\text { activities my jobs } \\
\text { offers. }\end{array}$} & No. & 21 & 29 & 24 & 57 & 20 & 150 \\
\hline & $\%$ of 150 & 14 & 19.1 & 15.8 & 37.7 & 13.4 & 100 \\
\hline & $\%$ of GT(1350) & 2 & 2 & 2 & 5 & 2 & 13 \\
\hline \multirow{3}{*}{$\begin{array}{l}\text { My job has enough } \\
\text { opportunity for } \\
\text { independent thought } \\
\text { and action. }\end{array}$} & No. & 15 & 23 & 18 & 61 & 34 & 150 \\
\hline & $\%$ of 150 & 9.9 & 15.2 & 11.7 & 40.4 & 22.8 & 100 \\
\hline & $\%$ of GT(1350) & 1 & 2 & 1 & 5 & 3 & 13 \\
\hline \multirow{2}{*}{$\begin{array}{l}\text { Grand Total (GT) of } \\
\text { responses in all } \\
\text { statements } 1350\end{array}$} & No. & 163 & 185 & 151 & 525 & 175 & 1200 \\
\hline & $\%$ of GT(1350) & 14 & 15 & 13 & 44 & 15 & 100 \\
\hline
\end{tabular}

Source: Author's own 
It can be observed from Table 9 that $50.3 \%$ of respondents are devoted to their organisation and they are prepared to do their best for the betterment of the company (48.3\%). From Table 9, it is inferred that $28.4 \%$ of employees reveal that the individual values and the company values are correspond to each other whereas $38.8 \%$ of employees are truly motivated by job environment.

Table 9: Level of Agreement for Organisation' Commitment

\begin{tabular}{|c|c|c|c|c|c|c|c|}
\hline \multirow{2}{*}{$\begin{array}{l}\text { Organisation' } \\
\text { commitment }\end{array}$} & & \multicolumn{5}{|c|}{ Level of Agreement } & \multirow[t]{2}{*}{ Total } \\
\hline & & 1 & 2 & 3 & 4 & 5 & \\
\hline \multirow{3}{*}{$\begin{array}{l}\text { For me this is the best } \\
\text { of all possible } \\
\text { companies/firms for } \\
\text { which to work. }\end{array}$} & No. & 14 & 31 & 14 & 68 & 23 & 150 \\
\hline & $\%$ of 150 & 9.5 & 20.8 & 9.6 & 45 & 15.1 & 100 \\
\hline & $\begin{array}{r}\% \text { of } \\
\text { GT(1350) }\end{array}$ & 1.06 & 2.31 & 1.07 & 5.00 & 1.68 & 11.11 \\
\hline \multirow{3}{*}{$\begin{array}{l}\text { I am extremely glad } \\
\text { that I chose this } \\
\text { organisation to work } \\
\text { for, over others I was } \\
\text { considered }\end{array}$} & No. & 10 & 21 & 15 & 69 & 35 & 150 \\
\hline & $\%$ of 150 & 6.7 & 13.8 & 9.9 & 46.2 & 23.4 & 100 \\
\hline & $\begin{array}{r}\% \text { of } \\
\text { GT(1350) }\end{array}$ & 0.74 & 1.53 & 1.10 & 5.13 & 2.60 & 11.11 \\
\hline \multirow{3}{*}{$\begin{array}{l}\text { I am willing to put in a } \\
\text { great deal of effort } \\
\text { beyond that normally } \\
\text { expected in order to be }\end{array}$} & No. & 14 & 27 & 11 & 72 & 26 & 150 \\
\hline & $\%$ of 150 & 9.4 & 17.8 & 7 & 48.3 & 17.5 & 100 \\
\hline & $\begin{array}{r}\% \text { of } \\
\text { GT(1350) }\end{array}$ & 1.04 & 1.98 & 0.78 & 5.37 & 1.94 & 11.11 \\
\hline \multirow{3}{*}{$\begin{array}{l}\text { I feel very loyalty to } \\
\text { this organisation. }\end{array}$} & No. & 15 & 23 & 15 & 75 & 21 & 150 \\
\hline & $\%$ of 150 & 10.3 & 15.1 & 10.1 & 50.3 & 14.2 & 100 \\
\hline & $\begin{array}{r}\% \text { of } \\
\text { GT(1350) } \\
\end{array}$ & 1.14 & 1.68 & 1.12 & 5.59 & 1.58 & 11.11 \\
\hline \multirow{3}{*}{$\begin{array}{l}\text { I find that my values } \\
\text { and the organisation's } \\
\text { values are very } \\
\text { similar. }\end{array}$} & No. & 19 & 32 & 19 & 43 & 38 & 150 \\
\hline & $\%$ of 150 & 12.4 & 21.4 & 12.6 & 28.4 & 25.2 & 100 \\
\hline & $\begin{array}{r}\% \text { of } \\
\text { GT(1350) }\end{array}$ & 1.38 & 2.38 & 1.40 & 3.16 & 2.80 & 11.11 \\
\hline \multirow{3}{*}{$\begin{array}{l}\text { I would accept almost } \\
\text { any type of job } \\
\text { assignment in order to } \\
\text { keep working for this } \\
\text { organisation. }\end{array}$} & No. & 14 & 28 & 17 & 61 & 30 & 150 \\
\hline & $\%$ of 150 & 9.5 & 18.5 & 11.6 & 40.6 & 19.8 & 100 \\
\hline & $\begin{array}{r}\% \text { of } \\
\text { GT(1350) }\end{array}$ & 1.06 & 2.06 & 1.29 & 4.51 & 2.20 & 11.11 \\
\hline
\end{tabular}




\begin{tabular}{|c|c|c|c|c|c|c|c|}
\hline \multirow{3}{*}{$\begin{array}{l}\text { It would take very } \\
\text { little change in my } \\
\text { present circumstances } \\
\text { to cause me to leave } \\
\text { this organisation }\end{array}$} & No. & 17 & 29 & 20 & 59 & 25 & 150 \\
\hline & $\%$ of 150 & 11.2 & 19.2 & 13.3 & 39.4 & 16.9 & 100 \\
\hline & $\begin{array}{r}\% \text { of } \\
\text { GT(1350) }\end{array}$ & 1.24 & 2.13 & 1.48 & 4.38 & 1.88 & 11.11 \\
\hline \multirow{3}{*}{$\begin{array}{l}\text { There's not too much } \\
\text { to be gained by } \\
\text { sticking with this } \\
\text { organisation } \\
\text { indefinitely. }\end{array}$} & No. & 17 & 31 & 22 & 36 & 43 & 150 \\
\hline & $\%$ of 150 & 11.6 & 20.8 & 14.8 & 24.2 & 28.6 & 100 \\
\hline & $\begin{array}{r}\% \text { of } \\
\text { GT(1350) }\end{array}$ & 1.29 & 2.31 & 1.64 & 2.69 & 3.18 & 11.11 \\
\hline \multirow{3}{*}{$\begin{array}{l}\text { This organisation } \\
\text { really inspires the very } \\
\text { best in me in the way } \\
\text { of job performance. }\end{array}$} & No. & 22 & 29 & 20 & 58 & 21 & 150 \\
\hline & $\%$ of 150 & 14.5 & 19.2 & 13.2 & 38.8 & 14.3 & 100 \\
\hline & $\begin{array}{r}\% \text { of } \\
\text { GT(1350) }\end{array}$ & 1.61 & 2.13 & 1.47 & 4.31 & 1.59 & 11.11 \\
\hline \multirow{2}{*}{$\begin{array}{l}\text { Grand Total (GT) of } \\
\text { responses in all } \\
\text { statements } 1350\end{array}$} & No. & 143 & 250 & 153 & 542 & 263 & 1350 \\
\hline & $\begin{array}{r}\% \text { of } \\
\text { GT(1350) }\end{array}$ & 10.57 & 18.51 & 11.34 & 40.13 & 19.44 & 100 \\
\hline
\end{tabular}

Source: Author's own

Hence, HRM practices arouse a few behavioural issues apart from the betterment of skills and abilities of employees. It is significant that an organisation follows HRM practices that make best use of their employees. Presently, companies are encountering many challenges and competition. Therefore, to survive in such an atmosphere, HR Managers have to be on their feet all the time to grasp the modes to maximise the usage of available human resources for improving the company's performance.

\subsection{Conclusion}

The outcome of this study reveals that clusters of HRM practices are completely linked to enhanced employee contentment. Thus it can safely be concluded that efficient HRM practices surely contribute to employee happiness. There can be a number of ways and means to implement such practices. However, some of them that have a major positive impression on employee liking include performance evaluation, training and development, employment selection, compensation and social benefits. They are amalgamated as the noteworthy variables in elucidation of the variance in employee dedication. 
Employee satisfaction precedes customer-centric strategic management. In other words, for any organisation it is rather impossible to attain success without first achieving the contentment in the work force. When employees are happy, the ultimate fallout is customer satisfaction, which eventually improves the profitability and goodwill of the company. Company must therefore, allocate required money and time to frame suitable training modules and to implement policy beneficial to employee's development, fair and unbiased promotions, compensation and welfare schemes on regular basis. The findings of this study also indicate that better HRM practices have immense positive impact on employees in the form of higher degree of satisfaction, dedication and higher retention which ultimately results in eventful success of the organisation. These findings are likely to be useful to management and work as a think tank to revisit HR practices that may be prevalent in organisations and in particular, the insurance sector.

\section{References}

Armstrong, M. (2006). A handbook of human resource management practice. 10th edition. London: Cambridge University Press.

Becker, B. E., \& Huselid, M. A. (1998). High performance work systems and firm performance: A synthesis of research and managerial implications. In G. R. Ferris (Ed.), Research in personnel and human resource management. Greenwich, CT: JAI Press, 16, 53-101.

Becker, B. E., Huselid, M. A., Pickus, P. S, \& Spratt, M. F. (1997). HR as a source of shareholder value: Research and recommendations. Human Resource Management, 36(1), 39-47.

Crook, T. R., Todd, S. Y., Combs, J. G., Woehr, D. J., \& Ketchen, D. J. Jr. (2011) Does human capital matter? A meta-analysis of the relationship between human capital and firm performance. Journal of Applied Psychology, 96(3), 443-456.

Delery, J. E. (1998). Issues of fit in strategic human resource management: Implications for research. Human Resource Management Review, 8(3), 289-309.

Fitz-enz, J. (1995). How to measure human resources management. New York: McGraw-Hill. 
136 | MANTHAN: Journal of Commerce and Management, Volume 4, Issue 2, Jul-Dec 2017

Guest, D. E. (1997). Human resource management and performance: A review and research agenda. The International Journal of Human Resource Management. 8(3) 263276.

Jiang, K., Lepak, D. P., Hu, J., \& Baer, J. C. (2012). How does human resource management influence organizational outcomes? A meta-analytic investigation of mediating mechanisms. Academy of Management Journal, 55(6), 1264-1294.

Venkatraman, N., \& Ramanujam, V. (1986). Measurement of business performance in strategy research: A comparison of approaches. Academy of Management Review, 11(4), 801-814. 